\title{
As contribuições da Filosofia Mística de Santa Teresa de Ávila para espiritualidade prática
}

\author{
Leonardo Delatorre Leite* \\ Gerson Leite de Moraes**
}

\section{Resumo}

O artigo tem como objetivo promover uma análise dos principais aspectos e características da obra de Santa Teresa de Ávila através de uma abordagem sintética dos conceitos e pressupostos de sua Filosofia Mística, bem como de suas relações com a prática da vida espiritual em sua dimensão holística. Os escritos de Santa Teresa representam uma verdadeira "pedagogia do amor", ou seja, apresentam conselhos, lições e grandes ensinamentos para o crescimento na caridade cristã. Não obstante o caráter digressivo das obras de Teresa, suas reflexões são extremamente úteis e necessárias para construção de uma espiritualidade prática pautada nas virtudes e numa relação mais íntima com Deus.

Palavras-chave: Teresa de Ávila. Mística. Amor. Espiritualidade. Caridade.

\section{The contributions of the mystical philosophy of St. Teresa of Avila to practical spirituality}

\footnotetext{
Abstract

The following article has the objective of promoting an analysis on the main aspects and characteristics of the works of Saint Teresa of Avila through a synthetic approach of the concepts and presuppositions of her mystical philosophy as well as her practices

* Universidade Presbiteriana Mackenzie. Graduando em Direito e História pela Universidade Presbiteriana Mackenzie. Bolsista PIBIC-CNPq. Membro do Grupo de Pesquisa "Religião, Memória e Cultura" do CEFT (Centro de Educação, Filosofia e Teologia) da UPM. Autor do livro "Cosmovisão Cristã Aplicada", publicado pela Editora CRV. leonardoleite59@gmail.com

** Universidade Presbiteriana Mackenzie. Bacharel em teologia pelo Seminário Presbiteriano do Sul. Doutor em Filosofia pela Universidade Estadual de Campinas, UNICAMP. Mestrado em Filosofia pela Pontifícia Universidade Católica de Campinas. Coordenador e docente do curso de Teologia da Universidade Presbiteriana Mackenzie, CEFT.

gerson.moraes@mackenzie.br
} 
towards spiritual life in its holistic dimension. The writings of Saint Teresa represent a true "pedagogy of love", that is, words of advice, lessons and great teachings on the development of Christian charity. Notwithstanding the digressive character of Teresa's works, her reflections are extremely useful and necessary for the growth of a spirituality oriented by virtues and in a more intimate relationship with God.

Keywords: Teresa of Avila. Mysticism. Love. Spirituality. Charity.

\section{Las contribuciones de la filosofía mística de Santa Teresa de Avila a la espiritualidad práctica}

\section{Resumen}

El artículo tiene como objetivo promover un análisis de los principales aspectos y características de la obra de Santa Teresa de Avila a través de un enfoque sintético de los conceptos y suposiciones de su filosofía mística así como sus relaciones con la práctica de la vida espiritual en su dimensión holística. Los escritos de Santa Teresa representan una verdadera "pedagogía del amor", es decir, presentan consejos, lecciones y grandes enseñanzas para el crecimiento en la caridad cristiana A pesar del carácter digresivo de las obras de Teresa, sus reflexiones son extremadamente útiles y necesarias para construcción de una espiritualidad práctica basada en virtudes y una relación más íntima con Dios.

Palabras clave: Teresa de Avila. Místico. Amor. Espiritualidad. Caridad.

\section{Introdução}

Este trabalho dedica-se ao estudo da experiência mística da santa espanhola do século XVI, Teresa de Jesus, cujos escritos tornaram-se grandes clássicos da literatura cristã, especialmente pelos seus grandes ensinamentos destinados a uma vida espiritual centrada no crescimento da piedade prática. Teresa recebeu o título de "Doutora da Igreja", sendo a primeira mulher a receber o benefício de tamanho reconhecimento. Sua eminência consiste no fato de que foi uma das pioneiras na elaboração de uma doutrina teológica moral em consonância com os ensinamentos doutrinários da Igreja Católica a partir de suas experiências pessoais com o Sagrado.

O impacto de suas experiências místicas foi diferente de outros narrados nas histórias dos demais teóricos da teologia mística cristã, especialmente pela intensidade como Teresa relata tais acontecimentos.

O que torna a experiência mística de Teresa, ou seja, seu encontro com o Sagrado, tão peculiar, é o fato de que suas experiências são vivenciadas de forma profundamente amorosa: sua experiência de êxtase místico é representada tão profundamente em seu corpo, que Teresa o denomina de gozo, deleite, de tão intensa e visceral que se torna essa comunhão com o Absoluto. (BARBOSA, 2006, p. 01) 
Um aspecto importante da obra da respectiva Santa é a presença marcante da dualidade, que se manifesta continuamente em suas reflexões acerca da vida eterna. Ao mesmo tempo que Teresa contempla, sente e se deleita com o amor de Deus, o sofrimento se manifesta como algo inevitável: o corpo padece, a alma sofre e os sentidos ficam marcados por uma confusão atormentadora.

Mas, devemos deixar claro desde o começo: quando falamos de Teresa de Ávila estamos falando de uma mulher que da adolescência até o final de sua vida enfrentou sérios problemas de saúde, sendo estes especialmente graves entre os 18 e os 25 anos (...) Assim, podemos afirmar que Teresa vivia uma certa dualidade: ela ama e rejeita este mundo. Ama a beleza, o corpo, a própria vida; mas quando a dor e o sofrimento se tornam grandes — grandes demais para seu coração humano - e a as lembranças perdidas no passado aparecem, e as visões chegam, e os sonhos evocam uma outra vida, então Teresa rejeita este mundo, e deseja outro, no qual as dores do corpo não existam: onde com outro corpo (ou simplesmente sem corpo) ela poderia - finalmente desfrutar de paz e tranquilidade. (GUTIÉRREZ, 2003, p.129-130)

Além da constante dualidade, Santa Teresa se vale de metáforas para construção de sua Filosofia Mística. “O estilo dos místicos espanhóis é pura metáfora. Por esse motivo, seus escritos, não requerendo dos leitores uma preparação filosófica (nem teológica), adquiriram uma grande popularidade" (GUTIÉRREZ, 2003,p.128). Portanto, além de representar um grande nome da literatura cristã, Teresa também é tida como uma das maiores escritoras da literatura espanhola.

Os escritos da autora espanhola são repletos de digressões, carregadas de uma profunda sinceridade e disposição em ensinar acerca dos pilares da vida espiritual, criando com o leitor um vínculo de aproximação com a realidade e com as dificuldades cotidianas, especialmente pela autêntica espontaneidade com que descreve suas experiências. "Com estilo próprio, singular, a escrita de Teresa dialoga com o leitor, provocando interação, sendo atraente e, ao mesmo tempo, instigante (...)" (PRATES, 2016, p.54).

Ela se dirige também a nós como estivesse conosco face a face, e se monstra descontraída fazendo confidências pessoais. Desviando-se do tema sempre de novo, ela volta e meia cai em si (e pergunta: "onde é que eu estava mesmo? Oh! Sim...) e volta ao tema principal, retomando o fio da meada. Eis aí algo enlouquecedor e agradável ao mesmo tempo, pois as divagações da Santa são, com frequência, seus parágrafos mais apaixonantes e importantes (...) Pelo 
fato de ela nos falar com tanta intimidade e de se entusiasmar tantas vezes, os escritos teresianos nem sempre são sistemáticos (BIELECKI, 2000, p.29)

Digressões, dualidade e metáforas são instrumentos poderosos nos escritos teresianos, pois potencializam e familiarizam os leitores com as importantes lições deixadas pela mística. Enfim, a Filosofia mística de Santa Teresa proporciona grandes reflexões e ensinamentos para o desenvolvimento da Teologia espiritual cristã e do entendimento acerca da relação do homem com o transcendente. Sendo assim, um melhor estudo da santa espanhola se faz necessário para qualquer entendimento mais aprofundado da Filosofia da Religião, bem como da História da Igreja.

\section{Vida e obra de Santa Teresa: Breve biografia}

Teresa de Jesus nasceu na cidade de Ávila, Espanha, em 28 de março de 1515. Sua família, de origem judaica, converteu-se ao cristianismo, contudo, devido às condições históricas, preferiu esconder sua conversão ao catolicismo. Os pais de Teresa eram virtuosos e dedicados na educação religiosa dos filhos.

Dom Alonso, o pai, era um erudito, tinha uma enorme biblioteca e se deleitava com a leitura dos clássicos. Teresa, portanto, cresceu tendo contato com a cultura geral. Durante sua adolescência, apegou-se aos livros como pilares de seu crescimento intelectual e espiritual, como verdadeiros sustentáculos do progresso da alma no conhecimento da Verdade.

Um fato notável e relevante de sua infância era seu gosto pela meditação acerca da vida eterna. Mesmo quando criança, já nutria afeição pela religiosidade. Tamanha consideração de Teresa pelo transcendente que sua brincadeira favorita era brincar de "fundar mosteiros". A ideia da eternidade lhe atraía tanto que durante uma conversa com o irmão tomou a decisão de fugir de Ávila e se entregar aos mouros para morrer como mártir.

Mesmo mais nova, Teresa conseguiu convencer o irmão de qual tal sacrifício só iria fazer cair sobre seus pais mais graças. Convencidos partem os dois (...), todavia, foram encontrados pelo tio Francisco Alvarez de Cepeda que os levou de volta para casa. Teresa não se conformava em não ter conseguido seu intento. Para ela, a ideia de um gozo infinito valeria qualquer sacrifício, afinal seria a eternidade por um único ato (...). (BARBOSA, 2006, p.07)

Ainda adolescente, lia continuamente vários romances de cavalaria, um hábito herdado de sua mãe. Embora seu pai não aprovasse, Teresa encantava- 
se cada vez mais pelas histórias. Em seu relato biográfico "O livro da vida", a santa informa que começou a nutrir sentimentos de vaidade e apegar-se aos desejos de namoro. Contudo, tudo mudou quando sua mãe faleceu e as dores da perda a fizeram oscilar entre a devoção extrema e o abandono do fervor da piedade prática. Foi levada pelo pai ao Convento Agostiniano da cidade de Ávila, mesmo não concordando com tal imposição arbitrária. No convento, ainda tinha dúvidas acerca da vocação religiosa ou da constituição do matrimônio. Entretanto, entre 1553-1554, decide categoricamente se entregar a vida religiosa, mas dessa vez seu pai se opõe veementemente.

Em 1535 Teresa foge da casa paterna e entra no Mosteiro da Encarnação em Ávila. Vive vinte e sete anos (dos 20 aos 47 anos) no Mosteiro Carmelita da Encarnação. Com breves ausências em função de sua doença. Este mosteiro era uma comunidade monástica numerosa: em torno de duzentas pessoas entre religiosas e familiares residentes. Foram anos de formação. Foi neste mosteiro que aconteceu a segunda conversão de Teresa e sua iniciação na vida mística. Neste período igualmente já havia projetos de nova fundação. Mas tarde regressará como priora da comunidade (entre os anos de 1571-1574). (CARLI, 2017, p. 03)

A partir da confirmação de sua vocação religiosa, Teresa dedica-se a reformar a Ordem das Carmelitas, fundando o Carmelo São José de Ávila. Nesse momento, consolida sua fama como escritora e grande teóloga mística, associando-se até mesmo ao renomado teólogo do misticismo cristão São João da Cruz.

Nesse sentido, deve-se ter em mente que os escritos e a produção de Santa Teresa de Ávila encontram-se inseridos no contexto da Espanha do século XVI, marcado pelas consequências do processo de formação das monarquias nacionais com a expulsão dos mouros da península ibérica, pelo renascimento clássico, bem como pela reforma protestante. Nesse cenário, era marcante a atuação da Inquisição espanhola, que atuava tendo em vista a contenção e supressão dos valores racionalistas do Renascimento e das tendências de oposição aos dogmas católicos. Teresa aparece como uma representante da teologia mística dos pós Concílio de Trento, reafirmando os dogmas do catolicismo.

À vista disso, Teresa, assim como São João da Cruz, irá frisar alguns pontos essenciais da espiritualidade mística, tais como: a afirmação da presença de Deus no interior da alma (a chamada "inabitação trinitária”), a 
Gerson Leite de Moraes

dimensão afetiva da relação espiritual com o Criador e a profunda valorização da experiência pessoal. Embora a monja espanhola defendia veementemente a fé católica definida no Concílio de Trento, a Igreja não estava acostumada com os pressupostos da teologia mística, uma vez que os ideias tomistas da Escola de Salamanca ainda eram presentes na cosmovisão do catolicismo. Por este motivo, muitos membros do misticismo cristão tiveram problemas com a Inquisição, inclusive a própria Santa Teresa.

Vários foram os livros proibidos, ou em parte censurados. Desde 1521 que a Inquisição espanhola estendeu gradativamente sua jurisdição sobre a produção, circulação e posse de livros, enquanto que a Inquisição portuguesa lançou o seu primeiro Index em 1547 para, logo a seguir, em 1559, incluir nesse elenco um grande número de peças religiosas e outras obras significativas da espiritualidade "recolhida". O temor da heresia (...) levou o Santo ofício a estabelecer um controle rigorosíssimo (...) Tratava-se de censurar tudo o que fossem orientações que abrissem caminho a uma religião mais interiorizada, a uma aproximação individual com Deus. Esta é a razão porque não poucos místicos e ascetas tiveram problema com a Inquisição. Santa Teresa de Ávila não ficou isenta do controle inquisitorial. Mas, graças principalmente ao apoio particular de Felipe II, conseguiu levar adiante as suas buscas espirituais e criar novos mosteiros de Carmelitas Descalças. (BORGES, 2005, p.02)

\section{Fundamentos da Filosofia Mística de Santa Teresa}

A filosofia mística espanhola é resultado de uma cosmovisão pautada na junção dos elementos epistemológicos do neoplatonismo com os escritos dos autores cristãos clássicos, tais como: São Jerônimo, Santo Agostinho, São Gregório Magno, Tomás de Kempis e Francisco de Osuna. "A filosofia mística espanhola é o resultado duma fusão do neoplatonismo com o cristianismo, sem caráter reflexivo, mas se nutrindo do sentimento e deixando-se levar pela intuição” (GUTIÉRREZ, 2003, p.128).

Para melhor compreensão das nuances da filosofia de Teresa de Ávila, se faz necessário um esclarecimento acerca dos pressupostos da Mística Cristã. Rudolf Eisler, filósofo austríaco, procurou descrever os aspectos eminentes que compõem a experiência mística, a saber: o contato com o transcendente através da intuição e de uma experiência interior singular; a êxtase ocasionada por essa relação íntima com o espiritual, bem como a qualidade/peculiaridade fruitiva dessa conexão. 
Mística é a suposta apreensão do suprassensível, divino e transcendente (não pelos sentidos, não pela razão) mas através de uma experiência interior singular, através de uma intuição (intelectual) imediata, de uma contemplação, de uma vivência baseada em sentimento, de uma apreensão amorosa no estado de êxtase, de um esforço por submergir nas profundezas da própria alma para deste modo ter parte da união com o ser divino (união mística) de forma incompreensível e misteriosa. (EISLER, 2012, p.700)

O místico procura a união sem intermediários com o objeto do conhecimento, promovendo uma concepção de que o conhecimento do mistério se dá pela intuição. Segundo os teóricos, a mística é narrada enquanto uma experiência fruitiva, na medida em que se torna um fenômeno totalizante caracterizado pela anulação da distância entre sujeito e objeto, ou seja, o místico presencia uma relação de "quase-identidade" com o Absoluto. Sendo assim, na teologia mística medieval, essa união apresenta uma dimensão participativa e dinâmica do sujeito. "A mística irá indicar que o conhecimento de Deus requer uma penetração sempre mais profunda e a ultrapassagem das afirmações e das imagens que vão se constituindo na busca da elaboração de um saber sobre Deus" (MARIANI, 2012, p. 856).

Lima Vaz propõe uma relação tríade para compreensão da experiência mística. Trata-se da expressão "Místico-mística-mistério". Nesse sentido, o místico seria o sujeito da relação, o mistério corresponde ao Absoluto, o objeto; enquanto a mística seria uma reflexão acerca da conexão místicomistério. Enfim, o importante é frisar a intenção de união do sujeito com o Absoluto.

Ainda é possível distinguir entre diferentes formas de experiência mística na filosofia espanhola do século XVI. Henrique de Lima Vaz afirma que existem três formas de manifestação da experiência supramencionada, sendo elas: especulativa, mistérica e profética. "Na mística especulativa, a inteligência é elevada como que acima de si pelo ímpeto profundo de atingir em si mesmo o Absoluto na plenitude absoluta do ser" (VAZ, 2000, p.16). No tipo especulativo, há uma admissão de que o conhecimento humano subsume de forma mais elevada na contemplação, podendo elevar-se até o grau mais superior da consciência em que se dá a intuição ou percepção do Divino.

A mística mistérica se diferencia da especulativa na medida em que o espaço onde ocorre a experiência não é o espaço interior do sujeito, mas o espaço sagrado de um rito de iniciação. No entanto, por ser experiência, a mística 
mistérica é vivida no interior da consciência, contudo o objetivo dessa mística não será o cimo da alma como na especulativa e, sim, o conteúdo objetivo do mistério (...) Na mística cristã, o mistério é Cristo. Dessa forma, a presença do mistério, traz em si uma renovação e transformação interiores até atingir o ápice que seria o conhecimento do amor (...) (BARBOSA, 2006, p.39)

A mística profética, por sua vez, caracteriza-se por estar relacionada com a audição da Palavra de Deus, palavra que se transforma na prática piedosa das virtudes e dos frutos do Espírito. É uma mística que floresce no campo da Palavra Revelada, ouvida e obedecida, tendo em vista o caminho da santidade e da perfeição crista: o Amor Ágape ou caridade. Existe ainda um processo de Mediação na mística profética, pois para contemplar o Divino, deve-se passar pela imagem de Deus encarnada- Jesus Cristo. A mediação criatural consiste no reconhecimento humano da Soberania de Deus e da dependência de seu Amor, ao passo que a Mediação da Graça é marcada pela ação do Criador na condução do espírito humano nessa união. As distinções da experiência mística apontadas por Henrique de Lima Vaz ajudam no processo de compreensão das obras espirituais de Santa Teresa, especialmente no esclarecimento de seus relatos e vivências.

Enfim, as principais características da filosofia mística espanhola do século XVI são marcadas por uma profunda devoção pessoal, cujas dimensões abarcam uma série de práticas próprias, tais como:

a) Vida espiritual intensa; b. importância dada a oração mental; c. caráter prático e realista; d. profundeza teológica e atenção devida aos aspectos psicológicos; e. notável aspecto literário, uma vez que "todos os nossos grandes místicos são poetas, embora escrevam em prosa”; são portanto, "extraordinários em nossa mística o valor formal da exposição e o valor estético do estilo. Essas qualidades expositivas contribuíram para a difusão da literatura mística. (BORRIELLO; CARUANA; DEL GENIO; SUFFI, 2003, p.372)

Portanto, traçada uma visão panorâmica da filosofia mística geral, é possível adentrar nas nuances da perspectiva teresiana acerca de suas experiências com o Divino. Primeiro, é importante salientar que o estilo literário de Santa Teresa é marcado por uso constante de metáforas e digressões, tendo em vista uma maior proximidade com o leitor. Sua espontaneidade na escrita é talvez seu grande traço distintivo. São pontos cruciais na mística da santa espanhola: a Mediação pelo Senhor Jesus Cristo, 
experiência de Deus, o encontro de si, a relação de Amizade com o Criador, união de Amor e importância da meditação acerca da Humanidade de Cristo como condição para o progresso na vida espiritual.

Teresa frisa, de forma categórica, a necessidade de mediação pelo Cristo, bem como da importância da contínua meditação acerca de sua humanidade. "Em um primeiro momento, o Deus de Teresa ainda é distante, um Deus pai que se mantém afastado de suas criaturas pela imponência de sua perfeição" (BARBOSA, 2006, p.39). Contudo, é com uma experiência pessoal e consciente de Cristo que sua vida espiritual se torna fértil e fecunda. Deus se torna próximo na dor e nos sofrimentos de Jesus. "A humanidade de Cristo recebe, na espiritualidade teresiana, um valor absoluto (...)" (PADUA, 2003,p.166-167).

A palavra-chave usada por Teresa para descrever sua experiência é união, união de Amor centrada na total entrega a Deus. " o amor constitui a essência mesma da mística teresiana” (SCIADINI, 2009, p.71). Tamanho êxtase de contemplar e sentir o Amor do Divino que Teresa irá relatar as manifestações corporais oriundas dessa união pautada na caridade perfeita.

Teresa fala sobre a experiência do amor de Deus no sentido corporal. Só quem passou por esse tipo de experiência pode compreendê-la, escreveu ela. Quando começa a chegar o amor divino - relata Teresa, o primeiro que sente é uma suavidade no interior da alma, tão grande, que parece que o Senhor está muito perto, ao lado. Logo vem às lágrimas, a satisfação e uma calma que sossega todas as potências. É como se lhe colocassem dentro dos tutanos uma unção muito suave: a experiência do amor de Deus toca até seus ossos. Um cheiro forte que a penetra completamente, seguido da sensação de que o suavíssimo amor de Deus se introduze suavemente em sua alma, mas não sabe dizer por onde entrou. Quando está nesse estado, nem sequer quer-se mexer, nem falar, nem mesmo olhar, por medo de o perder, pois ela não quer perder aquilo. Para ela o cheiro que sente - inspirando-se no livro de Cântico dos Cânticos - é o cheiro do peito do esposo, que é melhor que os melhores unguentos (...) Nesse momento o prazer é tanto que sente como se fosse desmaiar, como se ficasse suspensa nos braços divinos de seu Esposo, aconchegada ao lado dele e encostada no seu peito (GUTIÉRREZ, 2003, p.144-145)

Ademais, um relato notável nos escritos da monja espanhola é o fenômeno por ela narrado de sua "transverberação". De acordo com sua descrição, trata-se de uma experiência extraordinária do amor de Deus que tem por objetivo a concretização da comunhão da alma com o 
Criador. Conforme descrito em suas narrativas, uma "flecha divina" marcou profundamente seu coração.

Vi que trazia nas mãos um comprido dardo de ouro, em cuja ponta de ferro julguei que havia um pouco de fogo. Eu tinha a impressão de que ele me perfurava o coração com o dardo algumas vezes, atingindo-me as entranhas. Quando o tirava, parecia-me que as entranhas eram retiradas, e eu ficava toda abrasada num imenso amor de Deus. (TERESA DE JESUS, 2001, p.194)

Teresa irá afirmar que na busca da alma por uma relação mais próxima com o Criador, o próprio Deus é responsável por mover a alma humana, chamando-a a uma relação mais íntima Consigo. O homem possui, em seu âmago, um "toque suave da graça"- a chamada "graça atual suficiente", que constitui um chamado para participação na vida eterna e no Sumo Bem, na qual se encontra a verdadeira realização e plenitude do Ser humano. Sendo assim, "quando a alma busca a Deus, na verdade é ela a buscada" (BARBOSA, 2006, p.67). O homem, inicialmente, encontra-se perdido, confuso e incompleto; a menos que volte seus olhos para o Transcendente. A experiência de Deus e o encontro de si são conceitos intimamente relacionados. O autoconhecimento só é possível mediante um profundo conhecimento do Criador.

Por isso vos digo, filhas, que devemos pôr os olhos em Cristo, nosso bem, e em seus santos, e dali depreenderemos a humildade, e o entendimento há de enobrecer, e o conhecimento de nós mesmas não será rasteiro ou covarde; que, embora esta seja a primeira morada é extremamente rica e de tão grande valor que quem conseguir se livrar de seus parasitas não deixará de seguir adiante. São terríveis os ardis e manhas do demônio para que as almas não se conheçam nem compreendam seus caminhos (...) E a mim parece que jamais chegaremos a conhecer a nós mesmas se não procurarmos conhecer a Deus; contemplando Sua pureza, veremos nossa sujeira; considerando Sua humildade, veremos o quanto estamos longe de ser humildes. (TERESA DE JESUS, 2014, p.26-27)

Conforme supramencionado, a amizade com Deus tendo em vista a união perfeita, também conhecida como "matrimônio espiritual", é o verdadeiro objetivo da espiritualidade. Segundo Santa Teresa, o ápice da vida espiritual seria o desenvolvimento do chamado "amor esponsal" por Deus. "Teresa sente que ela e Deus são uma unidade, estão 
completamente unidos, e ela, como esposa santa, fará qualquer coisa para manter a unidade com seu esposo." (GUTIÉRREZ, 2003, p. 147)

O Senhor meu, e Misericórdia minha e Bem meu! Que bem maior quero eu nesta vida além de estar junto a Vós, que não haja divisão entre Vós e mim? Com esta companhia, o que pode tomar-se difícil? O que não se pode fazer por Vós, tendoVos tão perto? Que há para me agradecer, Senhor meu? De que me culpar, sim, há muito, porque não Vos sirvo. E assim Vos suplico, com Santo Agostinho, e com toda a determinação: "Dai-me, Senhor, o que me mandardes, e mandai-me o que quiserdes". Não Vos darei jamais as costas, com Vosso favor e ajuda. (TERESA DE JESUS, 1995, 4.8-9)

Enfim, quatro são as etapas descritas por Teresa para o progresso no processo místico. São elas: a quietude da alma; o estado de união, em que o sentimento da presença de Deus é marcante e contínuo, a êxtase (interrupção dos sentidos humanos) e por fim, a mística esponsal, a união perfeita. Contudo, para adquiri tal progresso, é necessária a observância de uma série de práticas primordiais para evolução no Caminho de Perfeição, tais como: o exercício das virtudes, o combate às distrações na oração e um maior grau de recolhimento. Em vista dos fatos mencionados, percebe-se que os ensinamentos de Santa Teresa foram primordiais para a concepção de espiritualidade prática.

\section{O caminho de perfeição: As virtudes necessárias para vida de oração}

Em sua obra "O Caminho de perfeição", Santa Teresa apresenta uma introdução à vida de oração, destinada diretamente às monjas descalças de Nossa Senhora do Carmo da Regra Primitiva, em especial às grandes irmãs do Carmelo São José de Ávila. Contudo, embora voltada aos indivíduos que já estão no caminho da santidade, a obra teresiana apresenta pressupostos gerais e fundamentais da jornada cristã rumo a espiritualidade centrada em Cristo. Para a monja espanhola, o início da vida sobrenatural é marcado pela virtude infusa da fé amalgamada com a benção da graça eficaz, um dom de Deus. Sendo assim, para que seja possível progredir no caminho rumo à perfeição cristã, se faz necessário um esforço contínuo e sincero da alma no desenvolvimento e evolução da graça santificante, da qual:

descem às nossas faculdades as virtudes infusas, teologais e morais, e os sete dons do Espírito Santo; virtudes e dons que são como as funções 
subordinadas de um mesmo organismo, do organismo espiritual que se vai aperfeiçoando até a nossa entrada no céu. (GARRIGOU-LAGRANGE, 1950, p.55)

O fundamento de nosso organismo espiritual consiste, basicamente, em três coisas: a fé, a graça santificante e as virtudes infusas. Nesse sentido, Teresa irá explicar primeiramente acerca dessas virtudes necessárias e primordiais para o desenvolvimento de uma relação mais intensa com o Divino. Diante do exposto, três são as virtudes imprescindíveis citadas pela monja espanhola: o amor fraterno, o desapego de todo criado e a verdadeira humildade.

Vós me pedistes para falar da oração; em troca do que eu disser, peço-vos que observeis, lendo muitas vezes de boa vontade, o que até agora escrevi. Antes de falar do interior, isto é, da oração propriamente dita, direi algumas coisas que quem pretende seguir o caminho de oração precisa ter, coisas tão necessárias que as que as seguirem, mesmo não sendo muito contemplativas, poderão avançar muito no caminho do Senhor; é impossível, não as seguindo, ser muito contemplativa, e quem pensar que o é estará muito enganado (...) Não penseis, amigas e irmãs minhas, que vos encarregarei de muitas coisas (...). Só me alongarei em falar de três (...), porque é muito importante percebermos o grande proveito de guardar essas coisas para ter a paz interior e exterior que o Senhor tanto nos encomendou. A primeira é o amor de umas para com as outras (amor unas con otras); a segunda, o desapego de todo o criado (desasimiento de todo lo criado); a terceira, a verdadeira humildade (verdadera bumildad) - que, embora tratada por último, é a principal, abarcando todas. (TERESA DE JESUS, 2001, p.311-312)

A começar pelo Amor Fraterno, Teresa dirá que é impossível progredir na oração quem descuidar do amor ao próximo. A essência do verdadeiro amor, enquanto virtude infusa pelo Criador, consiste em ver Cristo no próximo, ou seja, amar o Cristo que se manifesta no irmão. Basicamente, quem ama de forma incondicional, deseja ao próximo a salvação eterna, o Sumo Bem e a participação na Bem aventurança. É possível verificar na obra teresiana uma tendência à concepção tomista de virtude, segundo a qual a prática virtuosa consiste em imprimir ao objeto a medida da razão, tendo em vista o Fim último: Deus. Portanto, realizar atos de forma intensa visando o Sumo Bem, que é Cristo, é a verdadeira virtude. Nesse sentido, quem promove a ordenação da razão em prol do Bem perfeito é o virtuoso autêntico. É nesse contexto que Teresa de Jesus insere o Amor Fraterno. 
Existe, na jornada espiritual, o amor meramente humano e o Amor Espiritual fraterno. Vale ressaltar que Teresa já exclui completamente o amor do mundo, ou seja, o apego às imperfeições responsáveis por levar a alma ao pecado mortal. "Já não falo dos maus amores, que destes Deus nos livre! É coisa do inferno; não há para que nos cansarmos em condenar tal amor, pois o menor de seus males está acima de toda exageração" (TERESA DE JESUS, 2001,p.321)

Quando se trata de coisas do inferno, nunca podemos nos cansar de denegrilas, pois não é possível exagerar o menor de seus males. Essas coisas, irmãs, não devem sequer estar em nossa boca, nem devemos pensar que existam no mundo; não devemos ouvi-las nem de brincadeira nem deveras, nem consentir que, diante de nós, sejam tratadas ou narradas semelhantes amizades. Para nada isso é bom, e o simples fato de ouvi-lo pode levar à perdição. (TERESA DE JESUS, 2001,p.321)

Conforme supramencionado, a santa quer deixar claro que não há progresso sem uma ruptura imediata com os amores que conduzem ao pecado mortal. Voltando aos amores lícitos, o amor meramente humano é uma preocupação de zelo e proteção para com o próximo, sentimento este que se empenha para proteção da vida natural do irmão. Contudo, conforme já ressaltado, o amor fraterno vai além, pois se preocupa com a salvação eterna. Querer verdadeiramente o bem de uma pessoa é querer e desejar o Céu (Glória eterna) para ela. Este é o amor que reproduz e imita o que "nos teve Jesus, nosso bom amigo", dizia Santa Teresa. Sendo assim, a essência do amor consiste na correção e instrução na Verdade. Nesse sentido, ama quem corrige, quem orienta o próximo no caminho da justiça e das virtudes, e não aquele que restringe suas relações sociais a meras bajulações, conivências cegas ou ao conformismo. Daí a importância de a vida contemplativa e intelectual ser uma vida de prática de caridade.

É por isso que a vida ativa, no apostolado, não é empecilho para a vida contemplativa, mas seu pleno cumprimento. Servir aos outros significa, acima de tudo, conduzi-los ao Céu: não basta dar aos mais pobres pão e moradia; é preciso dar-lhes o Pão da Vida e a Morada Eterna - o único bem que não lhes será tirado (cf. Lc 10, 42) ${ }^{1}$

AZEVEDO JÚNIOR, Paulo Ricardo de. A Caridade Fraterna. Disponível em: https:// padrepauloricardo.org/aulas/a-caridade-fraterna. Acessado em 22/05/2020 
Após a explicação acerca da primeira virtude, a autora irá discorrer sobre o desapego. Teresa retoma a concepção de que a finalidade da vida cristã é a comunhão e união com Deus, e a forma de conhecê-Lo aqui na Terra é pelo dom da fé, enquanto uma virtude infusa. Contudo, para crescer na fé é necessário sentir o toque suave da graça, o Verbo interno inscrito no coração do homem, contudo, é necessário que a alma se acostume com o silêncio, afastando-se das confusões e apegos do mundo. Sendo assim, o desapego é primordial. "Passemos agora ao desapego, que devemos ter, porque tudo depende dele, se for praticado com perfeição" (TERESA DE JESUS, 2001, p. 325).

Teresa costumava dizer que Deus não se dá a quem não se dá por inteiro. "Digo, tudo depende do desapego, porque se nenhum caso fizermos de todo o criado e abraçarmos somente o Criador, Sua Majestade nos irá infundir na alma as virtudes infusas(...) olhos fitos em Vosso Esposo " (TERESA DE JESUS, 2001, p. 325-326). Portanto, a renúncia de si mesmo, ou seja, a decisão de dar-se inteiramente a Deus é um dos elementos imprescindíveis para o caminho de perfeição.

O exercício do desapego consiste em viver a pobreza de espírito, cujo pilar essencial é manifestação do amor a Deus de forma holística, de tal forma que a cosmovisão cristológica ocupe cada esfera da vida pessoal. Mesmo que se tenha bens materiais, ocupações e patrimônios, é necessário viver como se não tivesse tais bens, de modo que Cristo seja suficiente para a felicidade plena. Diante do exposto, percebe-se que o desapego representa o exercício da prudência, pois o prudente tem consciência do valor incomensurável e inegociável das coisas do alto, do Divino e do transcendente.

Ademais, a alma nutre a virtude do desapego através de práticas de mortificações, compreendidas enquanto um remédio para combater o apego provocado e ocasionado pelas paixões e bens materiais. A liberdade consiste em nutrir um sentimento de independência em relação à vontade de satisfação dos desejos concupiscíveis e fúteis. O desapego cria homens livres.

Quanto a humildade, a monja espanhola afirma que se trata do atributo principal de uma comunhão com o Criador, pois constitui o fundamento da vida espiritual e, em última instância, abrange todas as outras virtudes. "E como este edifício (organismo sobrenatural) tem a sua fundação na humildade, quanto mais próximos de Deus estivermos, tanto mais deverá ser essa virtude, pois, se assim não for, tudo perderemos" (TERESA DE JESUS, 2001, p.82). Não é possível dissociar a humildade da magnanimidade, ou seja, da disposição em obedecer aos mandamentos de Deus e conselhos de Cristo. 
O sinal da humildade é a obediência, enquanto a soberba nos inclina a fazer a própria vontade e a buscar aquilo que nos exalta, e a não querer deixar-nos dirigir pelos demais, mas a dirigir os outros. A obediência é o contrário da soberba. Mas o Unigênito do Pai, vindo do céu para salvar-nos e sanar-nos da soberba, fez-se obediente até a morte na cruz. A obediência torna meritórios nossos atos e sofrimentos, de tal modo que, de inúteis que estes últimos poderiam parecer, podem chegar a ser muito fecundos. Uma das maravilhas realizadas por nosso Senhor é ter feito que fosse proveitosa a coisa mais inútil, como é a dor. Ele glorificou-a mediante a obediência e o amor. (GARRIGOU LAGRANGE, 1950, p.683)

$\mathrm{Na}$ obra teresiana, a humildade encontra-se intimamente relacionada com a disposição em obedecer a Deus. O princípio da humildade encontra-se no temor de Deus. “(...) por que razão Nosso Senhor tão amigo desta virtude da humildade e logo se pôs diante, (...) isto; porque Deus é a suma Verdade, e a humildade é andar na Verdade" (TERESA DE JESUS, 2001, Castelo Interior, VI 10,7-8 ). À vista disso, a autora continua: "o que entendo é que o alicerce da oração tem como base a humildade e que, quanto mais se humilha na oração, tanto mais a alma é elevada por Deus" (TERESA DE JESUS, 2001, P.146). Para Antônio Royo Marin, a humildade " é uma virtude derivada da temperança, que nos inclina a coibir o apetite desordenado da própria excelência, dando- nos o justo conhecimento de nossa pequenez e miséria, principalmente com relação a Deus" (MARÍN, 1962, p.355).

Um traço eminente da humildade consiste em contrariar a própria vontade, tendo em vista a necessidade de promover a correspondência da vontade pessoal com a vontade de Deus. Eis o maior grau de humildade segundo Santa Teresa. "Aprendemos a contradizer em tudo a própria vontade. Se empregardes nisto toda diligência, a pouco e pouco estareis no cume sem saber como" (TERESA DE JESUS,2018, p. 73).

Sendo assim, após uma exposição digressiva acerca das virtudes imprescindíveis para o crescimento da vida sobrenatural, a autora espanhola irá discorrer sobre a espiritualidade propriamente dita na prática das orações. De qualquer forma, grandes são as reflexões de Santa Teresa sobre as virtudes e grandes são seus impactos na teologia mística do Ocidente.

\section{A vida de oração segundo Santa Teresa De Ávila}

Acreditai-me e não vos deixeis enganar por ninguém que vos mostre um caminho que não seja o da oração. (Caminho de Perfeição, XXI, 6) 
A filosofia mística teresiana fundamenta-se quase que exclusivamente na centralidade da oração na vida cristã. Mas afinal, o que torna a oração tão importante na concepção dessa grande escritora espanhola? Em suas obras, Santa Teresa era categórica em afirmar a eminência do relacionamento pessoal com o Criador como uma forma de manifestação do verdadeiro Amor, amor este compreendido enquanto uma decisão sincera e humilde de obedecer totalmente ao Cristo. "Com Teresa compreendemos que tratar com Cristo é tratar com um amigo, pois o homem se relaciona com Deus por meio da oração compreendida através da chave da amizade que é estar em comunhão com Deus, compartilhar, receber e dar" (CARLI, 2017, p.3). "Para mim, a oração mental não é outra coisa senão tratar de amizade, estando muitas vezes tratando a sós com quem sabemos que nos ama" (TERESA DE JESUS, 2001, p.63).

A razão primordial para prática da oração é o Amor, uma vez que corresponder ao amor de Deus é transformante, é gratificante. Segundo Teresa, amar a Jesus eleva a alma humana." Para ela a relação com Cristo é uma relação de amor. "Fora dessa ralação nada importa. Fora dela ela é nada e não tem para onde ir. Assim, longe de seu esposo — de Deus — nada tem valor “(GUTIÉRREZ, 2003, p.146-147).

Importante frisar a influência de Ricardo de São Vitor na perspectiva teresiana sobre a progressão da caridade na vida de oração. Segundo o pensador supramencionado, existem três amores na jornada espiritual. Em um primeiro momento, Deus se mostra como Senhor e Criador, e quando há o reconhecimento dessa grandeza e superioridade do Divino, a alma desenvolve o amor servil. Já, ao chamar-se a si mesmo de Pai, Deus mostra como somos adotados, sendo que a admissão e admiração dessa adoção incondicional acaba por nutrir o Amor filial, cuja essência consiste na decisão de desapego do mundo e na determinação de seguir os conselhos do Cristo. Por fim, a etapa de perfeita caridade reside no Amor Esponsal; eis a finalidade da vida de oração apontada por Santa Teresa.

O Amor Esponsal é a verdadeira amizade com Deus. Trata-se de uma relação íntima e pessoal com o Cristo. "Para Teresa, orar é conversar com um amigo muito querido" (BARBOSA, 2006, p.48). "A oração-amizade não é uma técnica, mas uma forma de vida em humilde e permanente relação com Deus, fonte de vida e amor.” (PEDROSA-PÁDUA, 2012, p.765). Teresa também ressalta a importância da oração a partir da afirmação de São Tomás de Aquino segundo a qual "O amor não nasce subitamente, ele nasce de uma 
contemplação assídua do objeto amado"(TOMÁS, S.th. II-II, q.27, art.2). Destarte, a caridade cristã é fruto de esforço, de uma decisão profunda, sincera e perseverante; sendo que a forma mais eminente de manifestação de tal decisão é a oração.

O verdadeiro amor se forma pelo costume, cuja intenção última é a união afetiva entre o que ama e o objeto amado. Portanto, a decisão de busca constante pela união afetiva é o que norteia e inspira a prática da oração. Outros elementos listados por Santa Teresa de Ávila necessários para espiritualidade prática peculiar da oração são: realização do sinal da cruz, exame de consciência, confissão, arrependimento e por fim, acostumar-se com a presença da companhia de Cristo.

Certamente, o passo mais importante na oração é presença e companhia de Cristo, pois trata-se de uma verdadeira forma de amizade e intimidade. "Representai o próprio Senhor junto de vós e vede com que amor e humildade vos estais ensinando. Crede-me, filhas, acostumai-vos quanto puderdes a estar sempre com tão bom amigo, trazendo-o assim presente" (TERESA DE JESUS, Caminho de perfeição, 2018, p.150). Nutrindo essa relação de intimidade, as dores e sofrimentos tornam-se instrumentos de purificação e santidade. Destarte, suportar os males por Amor a Cristo é algo digno de uma verdadeira união afetiva, mas o verdadeiro símbolo do matrimônio espiritual consiste em promover uma correspondência entre as dores pessoais com os sofrimentos de Cristo, com a Sua Paixão.

Lembrando que Teresa foi uma mulher cuja vida foi marcada por doenças, crises existenciais e graves enfermidades, mas nunca deixou de contemplar o Cristo, meditando acerca de sua humanidade e compaixão." No Livro da Vida ela narra como a doença a acompanhou durante toda a sua vida, como lutou contra ela e como seu corpo viveu a dualidade de estar doente e estar cheio de "sensualidades" e de amor ao mesmo tempo"(GUTIERREZ, 2003, p.129).

Após uma visão panorâmica acerca da oração em geral, Teresa irá seguir explicando e discorrendo sobre os tipos e etapas do relacionamento com Deus, a começar pela oração vocal, cuja prática exige também um diálogo mental. "Quanto a mim, no que escrevo aqui, sempre que me lembrar, unirei oração mental com a vocal, para que ninguém vos assuste filhas" (TERESA DE JESUS, 2018, p.132). Portanto, o requisito indispensável para o desenvolvimento da oração vocal é a atenção, aqui entendida enquanto condição sine qua non para espiritualidade verdadeira, já que "quando rezais é justo entender o que dizeis". 
Existem, na teologia espiritual, quatro tipos de atenção exigidas para oração. São elas: atenção às palavras, atenção ao significado das palavras, atenção ao fim da oração e atenção ao objeto. Outro passo exigido para realização da prece vocal é a solidão, no sentido de recolhimento. “ (...) nos ensina Sua Majestade que alma se recolha a sós na solidão. Assim, fazia Ele sempre que orava, não por necessidade, mas para nosso ensinamento (...) é intolerável falar ao mesmo tempo a Deus e ao mundo" (TERESA DE JESUS, 2018, p.141). Para adquirir tal hábito, se faz necessário manter o pensamento unido àquele a quem se dirigem as palavras, evitando distrações e eventuais perturbações, tendo em mente que Deus está no interior da alma.

A pedagogia da oração-amizade implicará também outros elementos, como a prática do recolhimento - é necessário entrar no próprio "castelo interior". Trata-se de uma interiorização que potencializa a capacidade de a pessoa se colocar conscientemente diante de Deus. Há uma educação progressiva do olhar, do escutar e do falar interiormente com Cristo. $\mathrm{Na}$ prática do recolhimento, expande-se a capacidade de empatia com os sentimentos de Cristo e, simultaneamente, a capacidade de autoexpressão. (PEDROSAPÁDUA, 2012, p.766)

Na teologia espiritual, a piedade prática é outro requisito para a realização da oração vocal com plenitude. Sendo assim, resumidamente, o tripé da reza vocal consiste na atenção, na solidão enquanto recolhimento e na verdadeira piedade. Mas afinal, o que torna a prece realizada vocalmente tão eminente? São Tomás responde com precisão: "Em primeiro lugar, a oração vocal excita a devoção interior; a segunda razão é que o homem sirva a Deus também pelo corpo, já a terceira razão é uma certa redundância da alma no corpo causada por uma grande afeição” (S.Th. II-II, q.83, a.12).

Segundo Santa Teresa, a oração do pai nosso é um exemplo clássico de prece vocal e deve ser feita continuamente, pois trata-se de uma forma de pedir a Deus as graças necessárias para nossa salvação, pois a finalidade mediata da oração é pedir aquilo que Cristo já quer nos dar, ou seja, os bens espirituais, sobretudo, as virtudes teologais (fé, caridade e a esperança); lembrando que os bens temporais podem vir a ser indiretamente úteis à salvação, na medida em que se subordinam aos bens espirituais.

Após muito tempo com a prática da oração vocal, Teresa parte para a meditação, compreendida pela Santa espanhola como um meio para potencializar o crescimento das virtudes e, sobretudo, de promover a correspondência do intelecto e da vontade numa união amorosa e afetiva. 
Tratando-se de meditação, seria possível falar e aconselhar que todos a façam, mesmo sem ter virtudes. A meditação é meio para alcançar todas elas (...) começar a meditar, para nós cristãos, é questão de vida ou morte. Ninguém, por perdido que esteja, deve deixar a meditação, quando Deus o convida a tão grande bem. (TERESA DE JESUS, 2018, p.90)

Destarte, a meditação consiste em deixar-se atrair pela beleza de uma verdade, englobando, assim, a parte intelectual amalgamada com o aspecto volitivo (a vontade); daí surgindo o afeto, do qual nasce resoluções e propósitos efetivos. Vale ressaltar que a meditação, enquanto um trabalho discursivo do entendimento, implica em uma atitude ruminativa de discorrer sobre determinada verdade, cuja beleza faz nascer um desejo ardente de ação evangelística.

A monja espanhola irá discorrer acerca dos principais assuntos que rendem boas meditações, a saber " a graça que Deus nos concedeu em nos dar Seu único Filho, e não paramos aí, avançando para os mistérios de toda a Sua Gloriosa vinda" (TERESA DE JESUS, Sextas moradas, XVII, 10) . A encarnação, o mistério da Humanidade e paixão de Cristo são as melhores verdades para perfeita contemplação.

A leitura seria a fase preparatória para a meditação propriamente dita e deve ter como base os Evangelhos. Posteriormente, um ato de humildade deve ser feito, seguido de um ato de contrição e, por fim, um ato de adoração. A parte específica da meditação é marcada principalmente pela preocupação com o crescimento das virtudes teologais (atos de caridade, fé e esperança). $\mathrm{O}$ ato de caridade, um dos mais eminentes, é afetivo e nutre propósitos efetivos, ou seja, molda uma disposição de não mais pecar.

Conforme o cristão progride na meditação em busca da verdade, percebe cada vez mais que essa verdade é uma pessoa. Neste momento, é que se dá a passagem da oração de meditação para prece afetiva. O que caracteriza categoricamente a oração afetiva é a presença de Deus no interior da alma, presença que é sentida de forma pessoal e muito mais perceptível. "A oração afetiva, em última análise, é também uma meditação; porém, é a meditação de alguém que já não fica preso a um livro, pois possui, dentro de si, um livro já escrito por Deus"'. Quem começa a trilhar esse tipo prece, nutre em sua alma afetos de união constantes e nítidos para com o Criador.

2 AZEVEDO JÚNIOR, Paulo Ricardo de. Oração Afetiva: o terceiro grau da oração. Disponível em: https://padrepauloricardo.org/episodios/oracao-afetiva-o-terceiro-grauda-oracao. Acessado em 23/05/2020. 
Conforme define Antonio Royo Marín, a oração afetiva é "aquela na qual predominam os afetos da vontade sobre o discurso do entendimento (...) em que vai tomando cada vez mais preponderância o coração sobre o trabalho anterior discursivo" (MARÍN, 1954, p.674). Mais especificamente, trata-se de uma espécie de meditação em que o trabalho ruminativo e discursivo do entendimento vai sendo sobreposto pelos afetos que procuram uma união fervorosa com Cristo.

Por fim, para o leigo cristão, a oração de recolhimento adquirido é uma das grandes conquistas no progresso da vida espiritual. Acerca deste modo de rezar, Santa Teresa escreve: "Chama-se recolbimento, porque a alma recolhe todas as faculdades e entra em si mesma com seu Deus" (TERESA DE JESUS, 2018, p.161). Recebe o nome de "adquirida" porque exige um esforço ativo e notável da vontade humana, mesmo que com apoio da graça divina.

Quisera saber declarar como essa corte santa vem com nosso companheiro, Santo dos santos, sem impedir a privacidade da alma e de seu Esposo quando ela deseja entrar em si, nesse paraíso com seu Deus, fechando atrás de si a porta a todas as coisas do mundo. Digo 'deseja' porque, entendei, isso não é coisa sobrenatural, estando em nossas mãos e sendo algo que podemos fazer com o favor de Deus, já que sem Este não podemos nada, sequer ter um bom pensamento. Porque isto não é o silêncio das faculdades, mas o encerramento delas no interior da alma. (TERESA DE JESUS, 2002, p.385)

Nesse sentido, sendo considerada uma oração para os leigos e principiantes, a prece de recolhimento adquirido tem um caráter predominantemente ascético, distinguindo-se da grandiosa experiência mística dos santos. Garrigou Lagrange estabelece tal diferença:

Partindo dos princípios de Santo Tomás de Aquino, da doutrina de São João da Cruz e também de São Francisco de Sales, a ascética trata da via purgativa dos principiantes que, entendendo que suas almas não devem permanecer atrasadas e na tibieza, se exercitam generosamente na prática das virtudes, ainda que dentro da maneira bumana dessas virtudes, "ex industria propria", com o socorro da graça atual ordinária. A mística, ao contrário, começa desde o momento em que se trata já da via iluminativa, lá onde os adiantados, iluminados pelo Espírito Santo, já operam, de modo frequente e manifesto, segundo a maneira sobre-bumana dos dons do Espirito Santo. Guiados pela inspiração especial do Mestre interior, não agem apenas "ex indústria propria", mas a maneira sobre-humana dos dons, até então latente, ou poucas vezes manifesta, se faz agora patente e ordinária. (GARRIGOU-LAGRANGE, 1950, p.21-22) 
A oração de recolhimento adquirido encontra-se intimamente relacionada com a inabitação trinitária, ou seja, com a presença de Deus no interior da alma. O cristão, nessa etapa da vida espiritual, deve entrar no "castelo interior" e gozar da beleza e grandiosidade da graça da companhia do Criador no âmago da alma. Contudo, para alcançar tal prática é necessário, na concepção de Santa Teresa, ter em mente que a Santíssima Trindade, Beatitude infinita, quer comunicar ao homem sua vida divina. $\mathrm{Na}$ teologia dogmática católica, a participação na vida eterna ordenada e sustentada por Deus se dá por meio da graça santificante. Em virtude dos fatos apresentados, percebe-se que a contemplação dessa verdade é condição sine qua non para oração de recolhimento adquirido.

Discorrido acerca dos graus de oração, Teresa irá falar propriamente sobre as dificuldades existentes durante o caminho de perfeição, bem como dos remédios, e métodos para combatê-las. A primeira grande dificuldade, consta a Doutora da Igreja, reside na dificuldade de muitos leigos de promover o recolhimento dos sentidos internos (memória e imaginação) e externos durante a execução oração. Tal dificuldade é extremamente perigosa para a disciplina, uma vez que tende a produzir e fomentar distrações durante as preces. O único modo de vencer essa debilidade é a educação da vontade e do intelecto, compreendidas enquanto potências superiores da alma responsáveis pela imposição da ordem aos sentidos.

A mística espanhola irá explicar as causas por trás das distrações. São elas: o caráter das verdades sobrenaturais (intelecto humano é finito, ao passo que Deus é infinito), a instabilidade das potências da alma (fraquezas decorrentes do pecado original), as doenças e defeitos que se inserem no caráter e no temperamento, a ação diabólica e por fim, a permissão divina. Apesar das inúmeras causas que originam os empecilhos para espiritualidade prática, Teresa irá comentar sobre os remédios e métodos de combate, a saber: discrição, perseverança e humildade.

A discrição consiste em não se afligir diante dos problemas e da conjuntura negativa. "Muitíssimas vezes tudo vem da indisposição corporal (...) Nesses momentos, quanto mais a quisermos forçar, tanto pior e mais duro será o mal; nesse caso, é preciso ter discrição para ver quando se deve fazer o quê, para não atormentar a pobre alma" (TERESA DE JESUS, 2001, p.80). A perseverança consiste no foco, ou seja, em direcionar continuamente os esforços na santidade, fugindo sempre que possível das frivolidades. Por fim, a humildade permite que a alma tenha ciência de seu estado decaído 
e de sua dependência da graça de Deus. Contudo, o mais importante é reconhecimento acerca da natureza e finalidade das tribulações. Todas as dificuldades e problemas estão dentro dos desígnios da amorosa Divina Providência e servem como instrumentos para a santidade. Vencê-las sem perder a fé é uma grande manifestação de amor.

Teresa finaliza suas ponderações sobre o caminho da perfeição deixando claro a essência de toda jornada do cristão pela santidade. "Tudo o que vos tenho aconselhado neste livro tem por fim aquele ideal que consiste em darmo-nos totalmente ao Criador, identificar nossa vontade com a sua e desapegarmo-nos das criaturas" (TERESA DE JEUS, 2018, p. 190). A essência reside no valor do sacrifício da vontade pessoal em prol do cumprimento da Vontade de Deus. Não importa a intensidade dos sofrimentos, das angústias e das crises existenciais, pois todas as dificuldades são instrumentos de purificação e crescimento da alma. As provações estão debaixo da Soberania Divina. Portanto, Teresa termina com uma grande lição prática: a evolução na vida espiritual consiste em adequar a nossa vontade à vontade de Deus.

Cumpra-se em mim, Senhor, a Vossa vontade, de todos os modos e maneiras que Vós, Senhor meu, quiserdes. Se desejais que eu tenha sofrimento, dai-me forças para suportá-los e mandai-os; se perseguições, enfermidades, desonras e necessidades, aqui estou, e não vou virar o rosto, Pai meu, nem há razão para dar-Vos as costas. Se o Vosso Filho deu em nome de todos esta minha vontade, não há razão para que eu falhe, mas sim que me façais Vós a graça de me dar o Vosso reino para que eu então o possa fazer, já que Ele me pediu que fizesse, deixando que disponhais de mim como de coisa Vossa, de acordo com a Vossa vontade. (TERESA DE JESUS, 2002, p.398)

\section{Considerações finais}

Santa Teresa de Ávila, grande Doutora da Igreja, é conhecida mundialmente pelos seus inúmeros escritos, cujas preciosas lições são passadas de geração em geração, inspirando cristãos a trilharem o caminho da santidade. Desenvolveu um papel importante no progresso da Teologia mística, cuja característica distintiva era a relação pessoal com Deus mediante a contemplação e as práticas de piedade prática. Ainda no século XVI, em meio à turbulência provocada pelas transformações da Baixa Idade média e início da Idade Moderna, Teresa frisava a eminência do conhecimento teológico formado a partir de uma experiência singular fruitiva com o Criador, 
bem como de uma amizade pessoal com Cristo; fazendo uma oposição, mesmo que implícita, aos pressupostos de racionalização da Escolástica Tardia e da Escola de Salamanca. A santa espanhola enfrentou uma série de problemas com a Inquisição espanhola, chegando até mesmo a sofrer duras repressões e imposições, contudo nunca deixou de escrever acerca de suas experiências místicas. Era categórica em afirmar a centralidade da oração e de uma vida pautada completamente na busca pela santificação, chegando a promover reformas na Ordem das Carmelitas.

Contudo, ela é mais conhecida pela sua verdadeira "pedagogia do amor". A partir de sua filosofia mística, construiu uma visão da espiritualidade pautada na união afetiva com Deus, cujo matrimônio espiritual perfeito se daria a partir de uma evolução gradual da vida de oração. Sendo assim, suas obras resumem etapas, lições e missões a serem cumpridas e exercidas fervorosamente para uma relação de intimidade com Cristo. Muitos alegam que seus escritos foram eficientes no cumprimento de seus propósitos originais, especialmente pela espontaneidade de Santa Teresa, cujo estilo de literatura é marcado por metáforas, digressões e linguagem extremamente poética.

O ponto mais marcante da filosofia de Santa Teresa de Jesus é o Amor, que se manifesta explicitamente como o pilar de toda sua teologia. O encontro amoroso com Deus é o propósito de vida da santa espanhola. Daí decorre a eminência da filosofia teresiana para espiritualidade prática, uma vez que todas suas lições se concentram no que deveria ser entendido como o Fim último da existência humana: a vida eterna, o Sumo Bem.

Enfim, a filosofia mística de Teresa tem muito a contribuir para a maneira como enxergamos a espiritualidade, a santidade e a vida de oração, além de incentivar o comprometimento total com a cosmovisão cristã, ao frisar a prática cotidiana das virtudes teologais tendo em vista a experiência de Deus e o encontro de si.

\section{Referências}

AZEVEDO JÚNIOR, P.R . A Caridade Fraterna. Disponível em: https://padrepauloricardo. org/aulas/a-caridade-fraterna. Acessado em 22/05/2020.

Oração Afetiva: o terceiro grau da oração. Disponível em: https://padrepauloricardo.

org/episodios/oracao-afetiva-o-terceiro-grau-da-oracao. Acessado em 23/05/2020. 
Gerson Leite de Moraes

BARBOSA, L.I. De amor e de dor: a experiência mística de Santa Teresa de Ávila. 2006. 107f. Dissertação de Mestrado. Universidade Federal de Juiz de Fora, Juiz de Fora, Minas Gerais.

BIELECKI, T. Teresa de Ávila: uma introdução à sua vida e escritos. São Paulo, SP: Vozes, 2000.

BORGES, C.M. Santa Teresa e a Espiritualidade Mística: a circulação de um ideário religioso no mundo Atlântico. In: Congresso Internacional de História Espaço Atlântico de Antigo Regime, 2005, Lisboa. Espaço Atlântico de Antigo Regime. Lisboa: Universidade Nova de Lisboa, 2005, p.01-10.

BORRIELlO, L (org) et al. Dicionário de Mística. São Paulo, SP: Edições Loyola, 2003.

CARLI, V.B.A. A vida de oração de Santa Teresa de Ávila como exemplo para vencer as fronteiras da fé. In: Seminário Internacional de Antropologia Teológica: Pessoa e Comunidade em Edith Stein, 2017, Porto Alegre: EDIPUCRS, 2017, p.01-08.

EISLER, Rudolf. Wörterbuch der philosophischen begriffe (German Edition). Antique Reprints: 2012.

GARRIGOU-LAGRANGE, R. Las Tres Edades de 1a Vida Interior. 3. ed. Ediciones Desclée de Brouwer: Buenos Aires, 1950.

GUTIÉRREZ, J.L.R. A Filosofia Mística de Teresa de Ávila. Revista Caminhando. Volume 8, n.1 [11], p.127-157, 2003.

MARIANI, C.M.C.B. Mística e Teologia: do desencontro moderno à busca de um reencontro contemporâneo. Horizonte, v.10, n.27, p.854, 2012.

MARÍN, A.R. Teología de la perfección Cristiana. BAC: Madri, 1954.

The Theology of Christian Perfection. Priory Press: Bangor, 1962.

PEDROSA-PÁDUA. L. Mística e profecia na espiritualidade cristã: O testemunho de Santa Teresa de Jesus. Revista Horizonte. Dossiê: Místicas religiosas e seculares. Volume 8, n.18, p.757- 778, 2012.

Teresa de Ávila: testemunha do mistério de Deus. Perspectiva Teológica (Belo Horizonte), Belo Horizonte-MG - BRASIL, v. 35, n.96, p. 155-186, 2003.

PRATES, A.E. Imaginação material e mística: traços dos quatro elementos naturais presentes na obra Castelo Interior de Santa Teresa de Ávila. 2016. 184f. Tese de Doutorado em Ciências da Religião. Pontifícia Universidade Católica de São Paulo, São Paulo, SP. 
SCIADINI, F.P. (org). Dicionário de Santa Teresa de Jesus. São Paulo, SP: LTr, 2009. TERESA DE JESUS. Escritos completos de Teresa de Ávila. São Paulo, SP: Loyola, 2001.

O Livro da Vida. 7.ed. São Paulo, SP: Editora Paulus, 1983.

Obras completas Teresa de Jesus. 2.ed. São Paulo, SP: Loyola, 2002. O Caminho de perfeição. 8.ed. São Paulo, SP: Editora Paulus, 1982.

O Caminho de perfeição. 16.ed. São Paulo, SP: Editora Paulus, 2018.

Castelo Interior ou Moradas. 9.ed. São Paulo, SP: Editora Paulus, 1980.

VAZ, H.C.L; Experiência Mística e Filosofia na tradição ocidental. São Paulo, SP: Loyola, 2000.

Submetido em: 25-6-2020

Aceito em: 1-6-2021 